\title{
堆肥化反応における水分の限界に関する研究
}

\section{THE MOISTURE LIMIT FOR OPTIMUM COMPOSTING}

\author{
金子栄廣*・藤田賢二** \\ By Hidehiro KANEKO and Ken̈̈ FUJITA
}

\begin{abstract}
Moisture content is usually used to evaluate the state of water in compost and it is a useful operational parameter. However it does not describe the state of water in terms of microbial activity, hence the upper and lower moisture limits for composting are indefinite.

In this paper, relationship between water activity $\left(a_{w}\right)$, which is numerically equal to the equilibrium relative humidity expressed as a decimal fraction, and respiratory activity was experimentally examined with several materials. The results show that water activity is useful as an index of lower moisture limit and a common standard, $a_{w}=0.94$, is proposed. Air flow tests were also performed with the materials of different moisture content. The results indicate the moisture content which causes clogging of air supply in compost layer is an upper moisture limit.
\end{abstract}

\section{1. 緒 論}

高速堆肥化（コンポスティング）は，都市廃棄物や下 水污泥等の有機性廃棄物の処理方式として注目されてい る.この方式の特長は，原料である廃棄物中の易分解性 有機物を微生物により分解，安定化することにより，農 地等への還元が可能な製品が得られることにある.しか し, 現時点においては, 解決すべき問題点が数多く残さ れており，中でも，反応を速やかに行わせるための環境 因子の制御方法の確立が急がれている.

著者らは,一次発酵過程における水分の影響に着目し, 実験室規模の実験を行い, 主として動力学的側面から検 討を加えてきた. その結果, (1)温度を一定に制御し, 十 分に通気を行った場合，含水率を 50 ～60\%に保つこと により反応速度を最大にできること, (2)堆肥化を行うこ 亡のできる水分量には上限および下限があること, (3)含 水率や含水比を水分の指標として用いた場合, 堆肥化を 正常に行うことのできる水分の範囲が原料によって異な ることなどを確認した11),2).

* 正会員 工博 東京大学助手 工学部都市工学科 ( 1113 文京区本郷 7-3-1)

** 正会員 工博 東京大学教授 工学部都市工学科 (同上)
一方，現実には，処理コストならびに製品等の輸送コ ストの低減, 装置の小型化などを促進するため, 可能な 限り水分の多い原料を受け入れることができ，また，可 能な限り水分の少ない製品が作れるような装置および運 転管理法の開発が望まれている. したがって, 最適水分 量よりも，堆肥化が可能な水分の上限および下限に関す る情報の方が重要な意味をもつといえる.

そこで, 本研究においては, 以上の点を考虑し, 水分 管理に関する検討を行った.

\section{2. 低水分領域における反応速度}

製品コンポストの水分を減らすことは，輸送コストを 低減させるとともに，製品を農地等へ還元する際の作業 性を向上させる，すなわち製品の価値を高めるという効 果がある. しかし, 堆肥化が微生物反応であるため, 水 分を減らし過ぎると微生物の活性が低下し，反応速度の 低下あるいは反応停止を起こし，製品の品質を悪化させ る.したがって, 一次発酵過程においてどこまで水分を 低下させても差し支えないかという点について検討する 必要がある.

また, 先に述べたように, 含水率や含水比を水分の指 標とした場合, 原料によって堆肥化に必要な水分量の下 限が異なるという問題がある。したがって, 微生物の活 
性を反映し得る汎用性のある水分の指標を導入する必要 がある. 本章では, “水活性” (water activity) を水分 の指標とし, これと微生物の活性との関係について検討 することとした.

\section{（1）基 礎 式}

微生物が活動するためには十分な水分が必要であり, 物質が高濃度で存在する状況では微生物の活性が低くな る. このような観点から, いくつかの研究において水活 性と微生物の増殖速度との関係が論じられている ${ }^{3), 4)}$.

そこで，この考えをコンポストに適用する.

水溶液の水活性 $a_{w}$ は次のように定義されている ${ }^{5}$. $a_{w}=p / p_{0}$

ただし， $p$ および $p_{0}$ は，それぞれ，同一温度下におけ る水溶液の飽和蒸気圧および水の飽和蒸気圧である.

また, 溶液中の物質量と蒸気圧との関係は Raoult $の$ 法則 ${ }^{6}$ に示されている. すなわち, 理想溶液において, 溶質のモル数を $n_{1}$, 溶媒のモル数を $n_{2}$ とすれば,

$$
\frac{p_{0}-p}{p_{0}}=\frac{n_{1}}{n_{1}+n_{2}}
$$

という関係が成り立つ.そこでこれを変形し, 式 (1) に代入すると, 水活性と物質量との関係式が得られる.

$$
a_{w}=\frac{n_{2}}{n_{1}+n_{2}}
$$

この式より, 水活性が溶液の濃度の関数となっている ことがわかる. しかし，この関係をコンポストに適用す る場合，次のような配慮を要する．まずコンポストのよ うに溶質が単一でなく分子量が明確でない物質に対して は，溶質および溶媒の量的関係をとらえるのにモル数を 用いた表現では不便なため, 質量を用いた表現に変える 必要がある.また，固相と液相が混在するため，式（3) 中の溶質として水相に溶解している物質を用いなくては ならない。

そこで, 水の分子量を $M_{w}$, 溶解している物質の平均 分子量を $M_{s}$ とし, 式 (3) 中の溶質のモル数 $n_{1}$ を溶 解している物質量 $m_{s}$ に, 溶媒のモル数 $n_{2}$ を水の質量 $W$ にそれぞれ置き換えると次のようになる.

$$
a_{w}=\frac{W}{m_{s} M_{w} / M_{s}+W}
$$

さらに，水分量を含水比 $w$ を用いた形に直すと次の ようになる。

$$
a_{w}=\frac{W}{{ }_{x M_{w}} / M_{s}+w}
$$

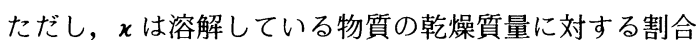
である.

\section{（2）実験方法}

a) 水活性の測定 水活性と含水比との関係を調 べるため, あらかじめ含水比を調整した試料の水活性を
Fig. 1 の装置により求めた．この装置は，広口ビン内に 封入した試料の飽和蒸気圧 $p$ およびその温度下におけ る水の飽和蒸気圧 $p_{0}$ を測定できるようになっている. そこで，その結果を式（1）に代入し，水活性を算出し た.

b) 微生物の活性の測定 好気性発醅では微生物 の增殖に伴って酸素が消費される. 特に, 反応が最も盛 んな, いわゆる対数増殖期において, 菌体増殖のために 消費される酸素量が菌体を維持するために消費される酸 素量に比べてはるかに多いとみなせば，この期間におけ る微生物の増殖速度と酸素消費速度との間に次のような 関係が成り立つと考えられる。

$$
d O_{2} / d t=Y_{0} d X / d t \text {. }
$$

ただし， $O_{2}$ は累積酸素消費量, $Y_{0}$ は比例定数, $X$ は菌 体量である．したがって, 酸素消費速度から微生物の活 性を知ることができる.

累積酸素消費量の測定装置を Fig. 2 に示す．この装置 は，ビン内の試料の酸素消費に伴って発生する二酸化炭 素をアルカリに吸収させることにより，酸素消費量を圧 力変化としてとらえることができるようになっている.

次に，このようにして求めた酸素消費量と時間との関 係から酸素消費速度を求める. 本来は, 酸素消費速度自 体が経時変化をするので, 各時点における酸素消費速度 を計算しなくてはならない。しかし，測定結果（Fig.5） にみられるように，酸素消費量の測定開始直後の数時間 にみられる酸素消費が少ない時期と, それ以後の酸素消 費量と時間とが直線関係になる時期とが存在する．そこ で，測定開始後数時間のデータを捨て，時間と酸素消費 量とが直線関係になっている部分について酸素消費速度 を算出した。

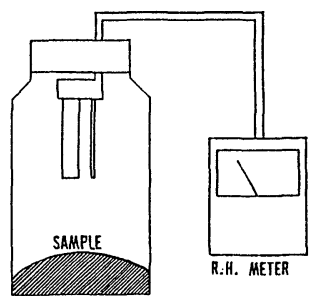

Fig. 1 Relative humidity meter.

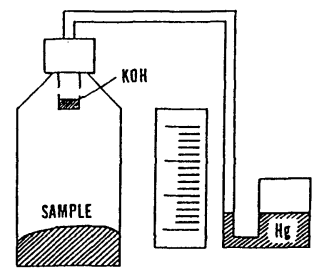

Fig. 2 Respiration apparatus. 
Table 1 Materials and Experiments.

\begin{tabular}{|c|c|c|c|c|}
\hline Sample & Contents & $a_{w}$ & $\mathrm{dO}_{2} / \mathrm{dt}$ & $\Delta \mathrm{H}$ \\
\hline SAMPLE & sawdust + dog food & o & 0 & 0 \\
\hline SAMPLE & newsprint + dog food & o & - & o \\
\hline SAMPLE & dog food & o & o & - \\
\hline SAMPLE M & sewage sludge compost & o & o & - \\
\hline SAMPLE & human waste sludge compost & o & o & - \\
\hline SAMPLE & sawdust ( under $1.41 \mathrm{~mm}$ ) & - & - & o \\
\hline SAMPLE $\mathrm{C}$ & sawdust $(1.41 \sim 2.0 \mathrm{~mm})$. & - & - & 0 \\
\hline COMPOST S & compost of SAMPLE $S$ & o & - & - \\
\hline
\end{tabular}

o : carried out - : not carried out

以上のようにして，あらかじめ水分を調整した試料の 酸素消費速度を測定することにより，水分量と微生物の 活性との関係を把握できる.

c）試料実験に用いた試料および測定項目を， Table 1 に示す.

\section{(3) 結果と考察}

a）水活性と水分量との関係 従来, 堆肥化過程 における水分管理を考える場合，水分量を表わす指標之 して含水率や含水比が用いられてきた。したがって, 新 しい指標として水活性を導入するに際し，これらの相互 関係を調べる必要がある. そこで，各試料に対して水分 量を変えて水活性を測定した.その結果を Fig. 3 に示す. 次に Raoult の法則より導出した式（5) をコンポス トに適用できることを確認する。式（5）を

$w / a_{w}=w+\varkappa M_{w} / M_{s}$

のように変形し，これに準じて各試料の含水比と実測値 より求めた $w / a_{w}$ との関係を調べると Fig. 4 のように なった。これより，どの試料においても $w$ と $w / a_{w}$ と が直線関係にあること，すなわち，実質的には式（7） の右辺第 2 項を定数とみなして Raoult の法則をコンポ ストに適用できることが明らかとなった。

そこで, 以後, 式 (7) に代わって, 右辺第 2 項を定 数 $K$ として扱った次式を用いて含水比と水活性との関 係付けを行うことにする.

$$
w / a_{w}=w+K
$$

または，

$$
a_{w}=\frac{w}{w+K}
$$

さらに, Fig. 4 に式（8）をあてはめ, 各試料に対す る $K$ の值を求めると Table 2 のようになった.

b) 水活性亡微生物の活性 水分量と微生物の活 性との関係を調べるため, 各試料に対し水分量を変えて それぞれの酸素消費量を測定した。そのときの乾燥試料 $1 \mathrm{~g}$ 当たりの累積酸素消費量の経時変化の一例を Fig. 5 に示す．その結果，水分が少なくなると酸素消費が遅く なることが確認された.

そこで，各試料に対して測定した酸素消費量の経時変 化から酸素消費速度を求め, 酸素消費量の測定を行った

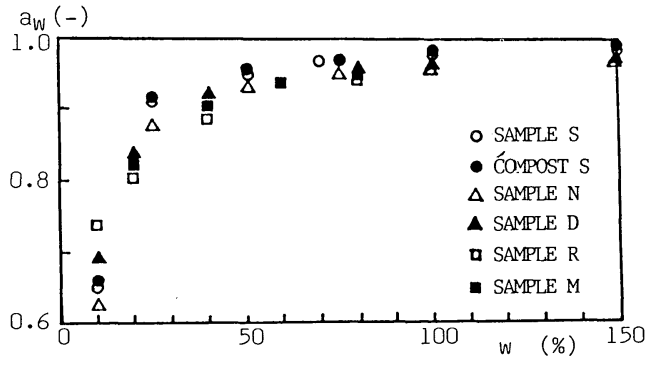

Fig. 3 Relations between $w$ and $a_{w}$

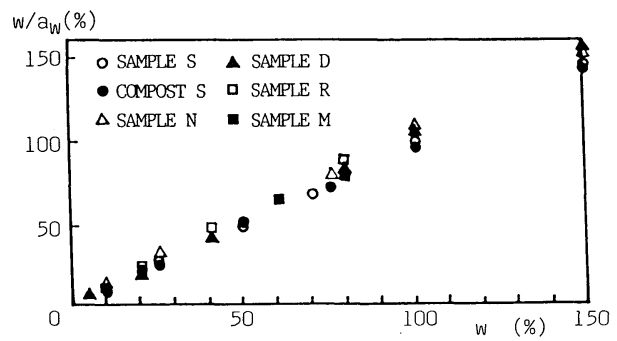

Fig. 4 Relations between $w$ and $w / a_{w}$.

\begin{tabular}{|c|c|c|c|c|}
\hline Sarmple & & K $(8)$ & Sample & K $(8)$ \\
\hline SAMPLE & $\mathrm{s}$ & 2.0 & SAMPLE M & 4.0 \\
\hline SAMPLE & $\mathrm{N}$ & 3.6 & SAMPLE $\mathrm{R}$ & 5.0 \\
\hline SAMPLE & D & 4.1 & COMPOST S & 2.2 \\
\hline
\end{tabular}

Table 2 Value of $K$.

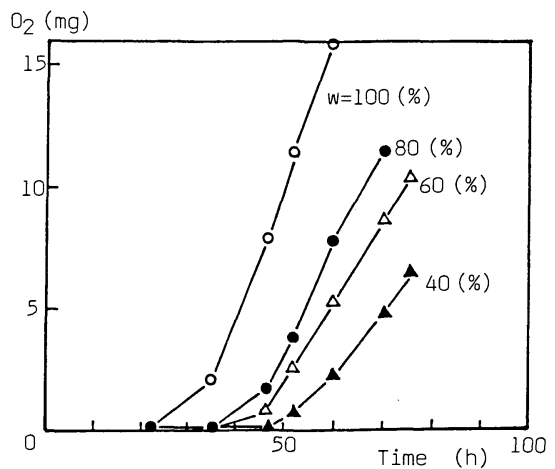

Fig. 5 Time course of oxygen consumption. 


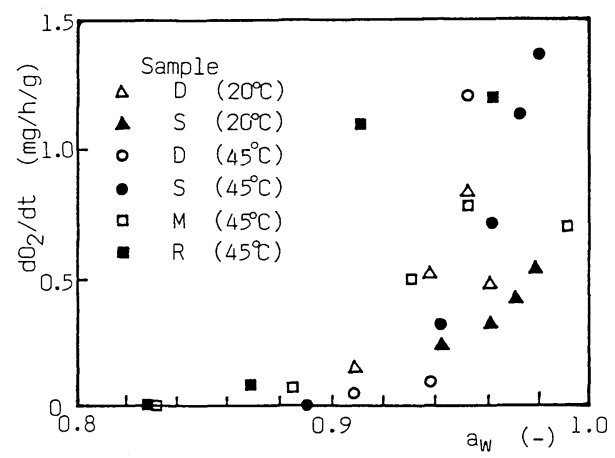

Fig. 6 Effect of water activity on respiration rate.

ときの水活性との関係をグラフ化すると Fig. 6 のように なる、これより，試料のいかんにかかわらず，水活性が 低下するに従って酸素消費速度が遅くなり，水活性が 0.9 より低くなると酸素消費がほとんど起こらなくなる ことがわかる.

c）一次発酵過程における水活性の影響 水活性 を一次発醅過程における水分管理に利用するに際し，水 活性が現実の一次発酵によ゙のように影響を及ぼすかを検 討する必要がある.

著者らは別の論文 ${ }^{2}$ において，おがくずとドッグフー ドの混合物（SAMPLES）および新聞紙とドッグフー ドの混合物（SAMPLE N) を原料として用い，定温条 件下で発酵実験を行い，ここで観測される分解率 $r$ が Contois モデル ${ }^{7)} り$ 導出した次式によって表現され得 ることを示した.

$$
t=-\frac{k Y_{x}}{\mu_{m}} \ln \left(r_{u}-r\right)+\frac{1}{\mu_{m}} \ln r+c
$$

ただし， $t$ は発酵時間， $k$ は Contois の定数， $Y_{x}$ は菌 体収率， $\mu_{m}$ は最大比増殖速度， $r_{u}$ は最終分解率， $c$ は 定数である.

そこで，この 2 種類の試料に対して，発酵実験より算 出した最大比増殖速度と水活性との関係について調べる

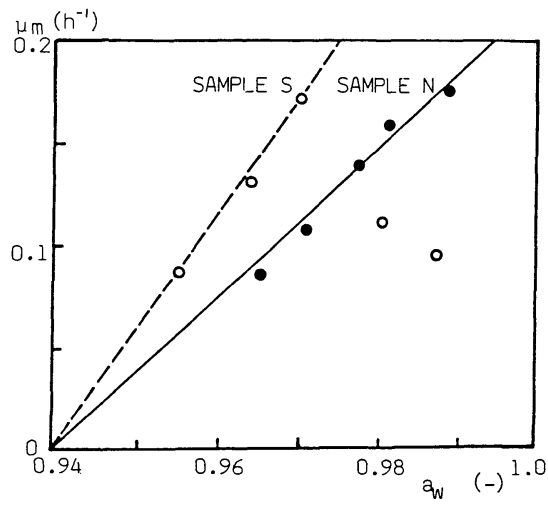

Fig. 7 Relations between $a_{w}$ and $\mu_{m}$.
と Fig.7 のようになる.これによると，少なくとも水分 の少ない領域において両者の間に直線関係が成り立つこ とがわかる．また，この直線上において $\mu_{m}=0$ となる 之きの水活性の值が両試料で一致しており， $a_{w}>0.94$ の領域において次の関係が成り立っている。

$$
\mu_{m}=\mu_{a}\left(a_{w}-a_{w 0}\right)
$$

ただし， $\mu_{a}$ は定数， $a_{w 0}$ は $\mu_{m}=0$ となるときの水活性 である。なお， $a_{w}=0.94$ に相当する SAMPLE S およ び SAMPLE N の含水率はそれぞれ $24 \%$ および $36 \%$ である.

以上のことから，水活性は堆肥化に必要な水分の下限 を示す汎用性のある指標と考えることができる．また，

一般に細菌が増殖するには $a_{w}>0.95$ が必要とされてい $3^{5), 8)}$ が，Fig.7はこの考えを堆肥化過程にも適用でき ることを示している.

次に, 式（11）に式（9）を適用し, 含水比と最大比 増殖速度との関係式に直すと次のようになる。

$$
\mu_{m}=\mu_{w} \frac{w-w_{0}}{w+K}
$$

ただし， $\mu_{w}=\mu_{a} K /\left(w_{0}+K\right), w_{0}$ は $a_{w}=a_{w_{0}}$ のときの含 水比である.

さらに, 含水率 $M_{c}$ と最大比增殖速度との関係式は以 下のようになる.

$$
\mu_{m}=\mu_{M} \frac{M_{c}-M_{c 0}}{M_{c}+K^{\prime}}
$$

ただし， $\mu_{M}=10000 \mu /\left(100-m_{c 0}\right) /(100-K), K^{\prime}=100$ $K /(100-K), M_{c 0}$ は $a_{w}=a_{w 0}$ のときの含水率である.

したがって, 最大比增殖速度に対する水分の影響を含 水比や含水率の関数として表現すると，限界值をもった Monod 型関数となることがわかる.

\section{3. 堆肥化可能な水分の上限}

水活性から考えると, 水分が多いほど微生物の活動に は有利ということになるが，好気反応を利用した堆肥化 過程においては水分が多くなると空隙が減少し, 酸素が 十分に供給されなくなるため反応阻害を起こす．著者ら は，堆肥化が可能な水分の上限が原料によって異なるこ と 2)ならびに，水分増加に伴いコンポストの比表面積が 低下することを確認した ${ }^{9)}$. しかし，原料が圧密を受け た場合の堆肥化可能な水分の上限を決めることはできな かった.

そこで，以下では，水分増加に伴う自重増加によって 生ずる気道の閉塞と水分の上限との関係について検討を 加えることとした.

\section{（1）実験方法}

Fig. 8 に実験装置を示す。あらかじめ水分を調整した 試料をカラムに充填し,下部より所定流量の通気を行い, 


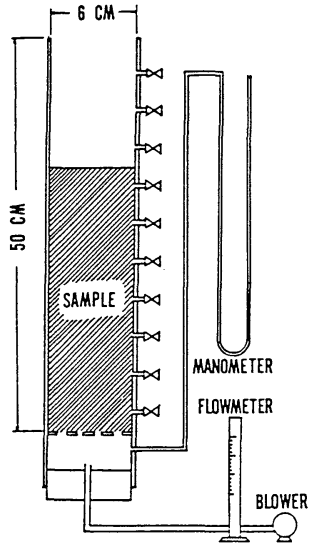

Fig. 8 Apparatus for air flow tests.

このときに要する送気圧（水頭差 $\Delta H ）$ を測定した。ま た, 試料の充媜状態の再現性を高めるため, 高さ $5 \mathrm{~cm}$ からの落下による突き固め回数 $N$ を統一した.

なお, 試料の充填厚は $30 \mathrm{~cm}$, 通気量は $3.0 \mathrm{l} / \mathrm{min}$ と した。

\section{(2) 結果と考察}

a) 水分量と気道の閉塞 試料の水分量を増やし ていくと送気圧は一般に次のように変化する.すなわち, 初めは, 自重の増加に伴って充垻密度が大きくなるため 送気圧が増加する. しかし，水分がある值以上になると 試料が粒団を形成し，見掛け上の比表面積が減少するた め, 送気圧は減少する.さらに水分が増えると，自重に よって粒団が押しつぶされ, 気道が閉塞するため, 再び 送気圧が増加する。この現象は Fig. 9 および Fig. 10 か らも読み取ることができる.

また, 堆肥化反応における分解の良否は最終分解率 $r_{u}$ に反映され，これが大きいほど分解が進んだことを

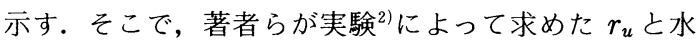
分量との関係についても Fig. 9 および Fig. 10 に併記し た。

試料別にみると,SAMPLE S の場合,含水比が $175 \%$ （含水率 $64 \%$ ）を超えると送気圧が減少から増加に転 じ，気道の閉塞が起こることがわかる，また，含水率を $65 \%$ にすると $r_{u}$ が小さくなり，十分な分解が行われ なくなることを示している.このことから，水分の上限 が気道の閉塞を起こす水分量とほぼ一致するといえる.

一方, SAMPLE N の場合, 気道の閉塞は含水比が $275 \%$ （含水率 $73 \%$ ）を超えると起こる. また, 含水 率が $75 \%$ になると $r_{u}$ が低下し，十分な分解が行われ にくくなりつつあるとみなすことができる.

このように, 堆肥化反応を進行させることのできる水 分の上限が，気道の閉塞を考慮することで決定され得る ことが明らかとなった。

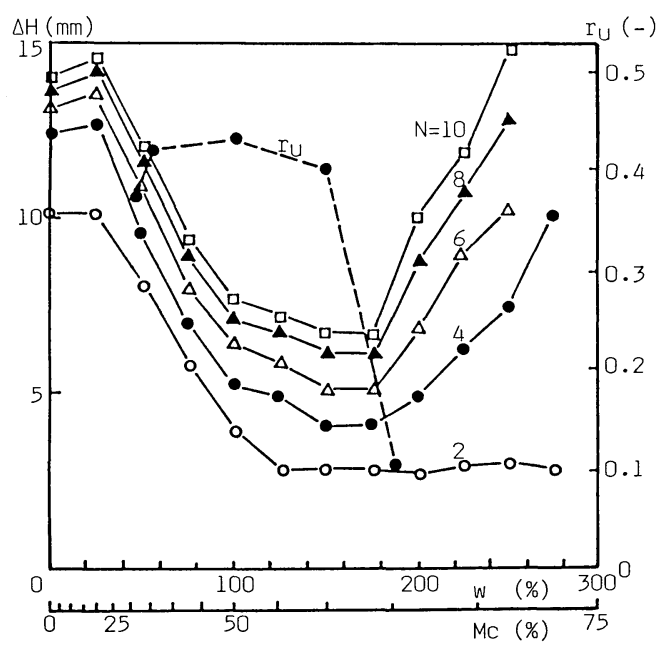

Fig. 9 Effects of moisture on $\Delta H$ and $r_{u}$ (SAMPLE S).

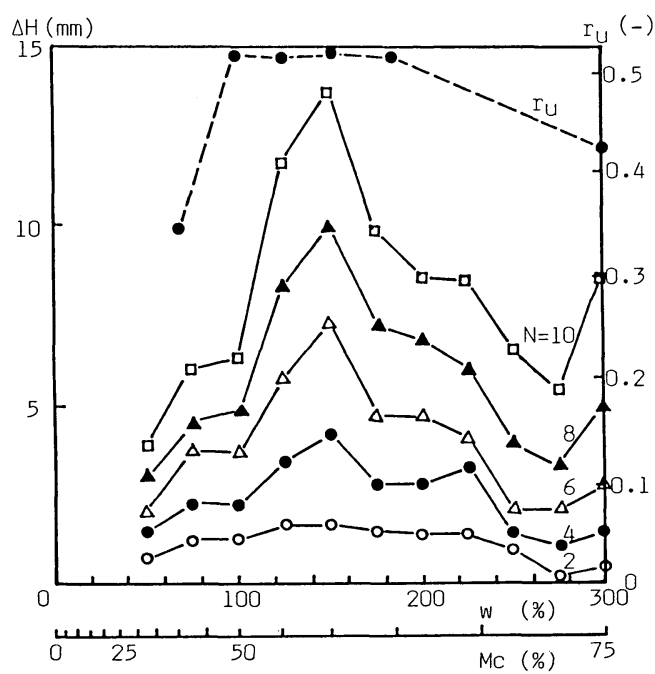

Fig. 10 Effects of moisture on $\Delta H$ and $r_{u}$ (SAMPLE N).

b）粒径との関係 同じ物質であっても粒径が異 なれば，閉塞を起こし始める水分量が変わると推察され る.そこで， $1.41 \mathrm{~mm}$ 以下にふるい分けしたおがくず (SAMPLE F) と $1.41 \mathrm{~mm} \sim 2.0 \mathrm{~mm}$ の粒径をもつお がくず (SAMPLE C) に対して，それぞれ突き固め回 数 $N$ を変えて水分量と送気圧との関係を調べた。

その結果を Fig. 11 および Fig. 12 に示す. 両者を比較 すると，粒径が大きいものほど比表面積が小さいことか ら, SAMPLE C の方が SAMPLE F に比べてかなり 送気圧が小さいことがわかる．また，粒径の大きいもの の方が水分量変化に伴う送気圧の変化が小さく, 水分に よる粒団形成が行われにくいことを示している.

気道が閉塞し始める水分量をみると, SAMPLE C の場合は含水比 $225 \%$ であるのに対し, SAMPLE F 


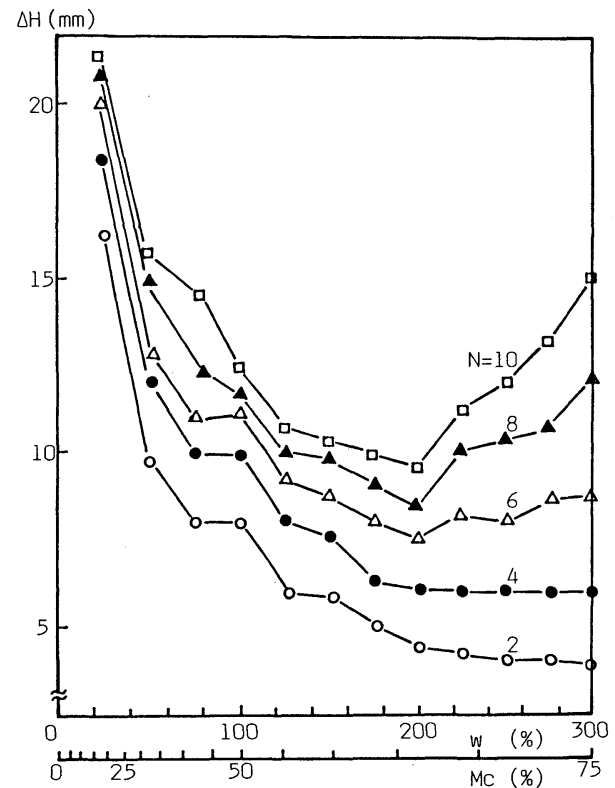

Fig. 11 Effects of moisture on $\Delta H$ (SAMPLE F).

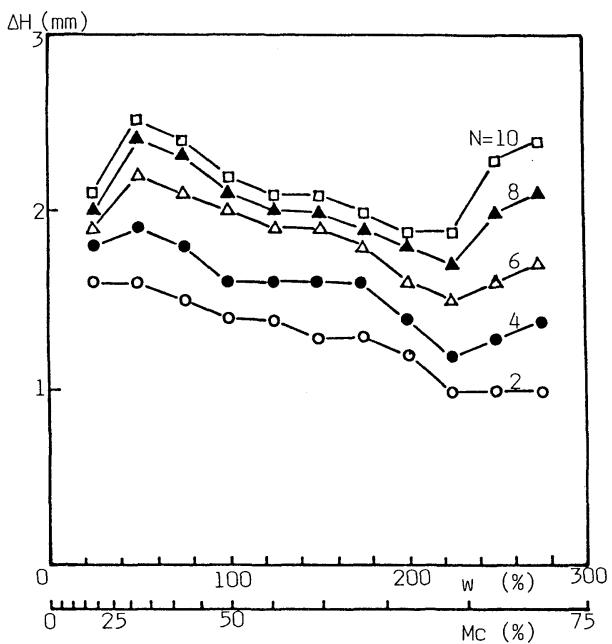

Fig. 12 Effects of moisture on $\Delta H$ (SAMPLE C).

の場合には含水比 $200 \%$ となっており，粒径が小さい ものほど閉塞を起こし始める水分量が小さいことがわか る.

したがって，比表面積を増やして反応速度を高める目 的で粒径を小さくし過ぎると, 気道の閉塞が起きやすく なり，かえって発酵にマイナス効果を与えることがある 之いえ．また，下水污泥のように，粒径が小さく，水分 を多く含むため, 閉塞を起こしやすい物質の通気性を改 善するために添加する bulking agents としては, ある 程度の粒径をもつ物質を用いるべきである.

\section{4. 結 論}

コンポストの一次発酵を適正かつ迅速に行うためには 水分を管理する必要がある。しかし，堆肥化が可能な水 分量の下限および上限が明確でないばかりでなく，従来 のように含水率や含水比を水分の指標として用いた場合 原料によってその值が異なるという問題があり，必ずし も効果的な水分管理が行われているとはいいがたい，そ こで本研究では, 汎用性のある指標の導入ならびに堆肥 化反応に必要な水分量の下限および上限の検討を行っ た。

まず，水分量の下限を示す指標として水活性を導入し 含水比との関係について調べた結果，次のことが明らか となった.

（1）コンポストの水活性 $a_{w}$ と含水比 $w$ との間には 次の関係が成り立つ。

$$
a_{w}=\frac{w}{w+K}
$$

また, 微生物の活性の指標として酸素消費速度を用い, これと水分量との関係について調へ，次のことを確認し た.

（2）水分量が減るとコンポストの酸素消費速度が低 下し, 試料の種類によらず水活性が 0.9 より小さくなる と酸素消費は起こらなくなる.

さらに, 著者らが求めた最大比増殖速度 ${ }^{2)}$ と水活性と の関係を調べたところ, 次のことが明らかとなった。

（3）水分の少ない領域において, 最大比増殖速度之 水活性との間に直線関係が成り立つ。

（4）含水率を指標とすると水分の下限値の異なる 2 種の試料に対し，水活性を指標として同一の下限值が得 られた。

（5）水活性は機器測定が容易で連続測定も可能なた め, 堆肥化過程における水分管理にとって非常に有用な 指標となり得る.

次に, 堆肥化が可能な水分量の上限について検討する ため, 水分量と気道の閉塞との関係について調べた. そ の結果，以下のことがわかった.

（6）気道の閉塞は, ある水分量を境にして起こり, この限界值は, 反応を正常に進めることができる水分量 の上限とほぼ一致する。

（7）同種の試料においては, 粒径の小さいものほど 閉塞を起こす水分量の限界值が小さい. したがって, 水 分調整のために添加する bulking agentsとしてはある 程度の粒径をもつ物質を用いるべきである.

また，今後は，水活性による水分管理を取り入れて発 酵実験を行い水活性の有用性をさらに確認するととも に，摫拌等の操作が水分の上限に及ぼす影響について検 
討する必要がある.

\section{使用記号}

$$
\begin{aligned}
& a_{w}: \text { 水活性 [一] } \\
& a_{w 0}: \mu_{m}=0 \text { となるときの水活性 [一] } \\
& c \text { : 分解率の経時変化に係る定数 }[\mathrm{h}] \\
& K \text { : 定数 }\left(\equiv x M_{w} / M_{s}\right)[\%] \\
& K^{\prime}=100 K /(100-K)[\%] \\
& k \text { : Contois の定数 [-] } \\
& \boldsymbol{M}_{c} \text { : 含水率 [\%] } \\
& M_{c 0}: a_{w}=a_{w 0} \text { のときの含水率 }[\%] \\
& M_{s} \text { : 水相に溶解している物質の平均分子量 [-] } \\
& M_{N}: \text { 水の分子量 }[-] \\
& m_{s}: \text { 水相に溶解している物質量 }[\mathrm{kg}] \\
& N \text { : 突き固め回数 [回] } \\
& n_{1}: \text { 溶質のモル数 }[\mathrm{mol}] \\
& n_{2}: \text { 溶媒のモル数 }[\mathrm{mol}] \\
& \mathrm{O}_{2}: \text { 累積酸素消費量 }[\mathrm{kg}] \\
& p: \text { 水溶液の飽和蒸気圧 }[\mathrm{atm}] \\
& p_{0}: \text { 水の飽和蒸気圧 }[\mathrm{atm}] \\
& r: \text { 分解率 }[-] \\
& r_{u}: \text { 最終分解率 }[-] \\
& t: \text { 時間 }[\mathrm{h}] \\
& W: \text { コンポスト中の水量 }[\mathrm{kg}] \\
& w: \text { 含水比 }[\%] \\
& w_{0}: a_{w}=a_{w 0} \text { のときの含水比 [\%] } \\
& X: \text { 菌体量 }[\mathrm{kg}] \\
& Y_{0} \text { : 酸素消費に関する定数 }\left[\mathrm{kgO}_{2} / \mathrm{kgcell}\right] \\
& Y_{x}: \text { 菌体収率 }[\mathrm{kgcell} / \mathrm{kgsubstrates]} \\
& x \text { : 水相に溶解している物質の乾燥質量に対す }
\end{aligned}
$$

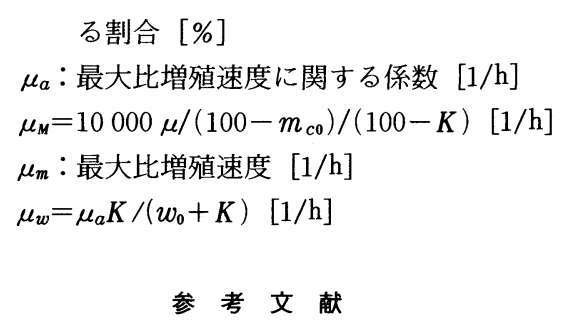

1）金子栄廣・藤田賢二：コンポスト化反応のパターン解析 と含水率の影響, 土木学会第 37 回年次学術講演会講演概 要集, 第 2 部, pp. 33 34, 1982.

2）金子栄廣・藤田賢二：堆肥化反応における水分の影響, 衛生工学研究論文集, Vol. 21, pp. 115 121, 1985.

3) Troller, J.A. : Effect of water activity on enterotoxin A production and growth of Staphylococcus aureus, Appl. Microbiol., Vol.24, No.3, pp.440 443, 1972.

4) Lotter, L. P. and Leistner, L. : Minimal water activity for enterotoxin A production and growth of Staphylococcus aureus, Appl. and Environ. Microbiol., Vol.36, No. 2, pp. 377 380, 1978.

5) Scott, W. J. : Water relations of food spoilage microorganisms, Adv. Food Res., Vol.7, pp. 83 127, 1957.

6) 化学ハンドブック編纂委員会編：化学ハンドブック, p. 442, 1978.

7) Contois, D.E. : Kinetics of bacterial growth : Relationship between population density and specific growth rate of continueous cultures, J. Gen. Microbiol., Vol.21, pp. 40 50, 1959.

8) Griffin, D. M. : Soil moisture and ecology of soil fungi, Bacteriol. Rev., 38, p. 141, 1963.

9）金子栄廣・藤田賢二：コンポストの水分量と比表面積の 関係, 土木学会第 39 回年次学術講演会講演概要集, 第 2 部, pp. 965 966, 1984.

(1985.7.15 - 受付) 